\title{
Indicators of Quality of Life to Compare Neighborhood Units and Regional Areas: A model to collect data in Turkish cities
}

\author{
Ebru Çubukçu*, İrem Erin
}

Department of City and Regional Planning, Faculty of Architecture, Dokuz Eylul University, Tınaztepe Kampüsü, Doğuş Caddesi No:209, İzmir 35160, Turkey

\begin{abstract}
Quality of life has been discussed in a wide range of contexts, including city and regional planning. Like other subjective parameters, it is hard to develop objective measures to understand "quality of life" for regions and specific urban settings. Since there has been voluminous literature on quality of life, researchers focused on various parameters to measure quality of life. This study aims to review the literature on quality of life to extract the indicators of quality of life in urban and regional settings. It would put forward a model to collect data to measure and compare quality of life in neighborhood units and regional areas. The model could be applied in Turkish cities. The potential and limitations of this model will be discussed.
\end{abstract}

(C) 2016. The Authors. Published for AMER ABRA by e-International Publishing House, Ltd., UK. Peer-review under responsibility of AMER (Association of Malaysian Environment-Behaviour Researchers), ABRA (Association of Behavioural Researchers on Asians) and cE-Bs (Centre for Environment-Behaviour Studies), Faculty of Architecture, Planning \& Surveying, Universiti Teknologi MARA, Malaysia.

Keywords: quality of life, micro/macro scale, neighbourhood unit, environment and behavior studies

\section{Introduction}

Quality of life is an extensive discourse which is subjected to various research in diverse disciplines. It is a multidimensional issue and a concern of a wide range of professions from medical studies to architecture or from economy to urban planning (El Din et al., 2013, Keles, 2012, Mohit, 2013a). For example, Mohit (2013a) listed 7 main disciplines (economics / political science, sociology / psychology, health studies, housing, marketing, cities level analysis, urban analysis; 3 of which are focusing on physical environmental and spatial issues) which studied the concept of QOL. Quality of life can be defined as overall wellbeing of societies and individuals in general. In the Dictionary of Human Geography it is explained as "A concept linked to that of social well-being, which is based on the argument that the human condition should be evaluated on a wider range of indicators than just income - whether at the individual level or through national aggregates." (Gregory, 2011).

Concerning environmental studies quality of life is a buzzword for decades and has taken seriously in developed countries since 1970 s and lately since 1990s in developing countries. Governments are seeking to reach a better and sustainable quality

* Tel.: +90-536-262-5460; fax: +0-000-000-0000 .

E-mail address: ebru.cubukcu@deu.edu.tr

(C) 2016. The Authors. Published for AMER ABRA by e-International Publishing House, Ltd., UK. Peer-review under responsibility of AMER (Association of Malaysian Environment-Behaviour Researchers), ABRA (Association of Behavioural Researchers on Asians) and cE-Bs (Centre for Environment-Behaviour Studies), Faculty of Architecture, Planning \& Surveying, Universiti Teknologi MARA, Malaysia.

DOI: http://dx.doi.org/10.21834/e-bpj.v1i2.282 
of life in their cities, because quality of life is considered as a domain of development and plays an important role in community satisfaction. Moreover, in contemporary era due to the increase in competitiveness, quality of life has become a fundamental concept in city marketing and place promotion. Thus, it is subjected to numerous research. In spite of voluminous literature on quality of life in environmental studies, two points are still challenging researchers (1) the meaning of quality of life (Dülger Türkoğlu et al., 2009, Mohit, 2013a) and, (2) defining the parameters and standards in measuring the quality of life (Dülger Türkoğlu et al., 2009, Keles, 2012, Khalil, 2012). This challenge occurs because the phenomenon of quality of life is an extensive issue with wide range of indicators and its parameters of measures change from research to research, city to city, culture to culture and scale to scale. For example, Mohit (2013a) argued that QOL has more than a dozen definitions. The authors of the present paper claim that there could be a common definition for QOL for all countries. Yet, one common instrument to measure QOL would not fit to all countries in all conditions. In other words, there could be a universal definition but there should be universal parameters for macro scale comparisons and local parameters for micro scale comparisons. Similarly, World Health Organization (WHO), as well as Organisation for Economic Co-operation and Development (OECD), developed a common international - cross cultural instrument to measure and compare QOL in countries (Mohit, 2013a). Also, Mohit (2013b) discussed the intention of developing Malaysian Quality of Life Index and criticized it for not being uniform across the fourteen states/ regions in Malaysia. Same applies to Turkey, there is no uniform instrument to measure and compare QOL in different regions, cities and neighbourhoods. This paper highlights the necessity to develop such instruments for Turkish regions, cities, and neighbourhoods.

This paper first aims to overview the quality of life studies in literature to understand the approach of researchers towards the discourse and extract the indicators of quality of life in both macro and micro scales. It then attempts to develop a model to measure quality of life dimensions in Turkey, regarding the physical and social structure Turkish cities.

\section{Methodology}

Twenty studies were overviewed for this research, which were selected regarding the discipline of "environment and behaviour", and with the concern of geographical diversity. The studies were from Turkey, USA, India, Argentina, Italy, Tunisia, Egypt, Cyprus, Iran, Malaysia covering cities Istanbul, counties of USA, Guwahati, La Plata, Agrigento, Bologna, Cesena, Florence, Grosseto, L'Aquila, Latina, Matera, Palermo, Pescara, Salerno, Tunis, Sousse, Sfax, AlShohada and Bad, Famagusta, Tehran, Kuala Lumpur, Petaling Jaya, Shah Alam, and Klang. The spectrum of indicators was extensive and the parameters varied from economic, social, political to physical environment. Correspondingly, indicators of physical environment vary in scale from housing to regional. Eight studies assessed quality of life in macro scale, nine in micro, and three in both. Seven studies were conceptual and thirteen were empirical. Among empirical ones ten measure quality of life with subjective data, two with objective data, and one in both. Majority of empirical studies' data derived from research based data (Table 1). Only one empirical study used national database and three used both types of databases. In some papers indices of quality of life were narrow (like one parameter), but in others parameter list could be broad (more than 50 parameters). For example, Hassine et al. (2014) inspected quality of life solely in terms of air quality and Lloyd\&Auld (2003) solely in terms of public spaces. On the other hand, Türkoğlu (2011) used more than 50 parameters to measure quality of life.

Other than examining research in literature, this study investigated Organisation for Economic Co-operation and Development's (OECD), World Health Organization's (WHO) and Turkish Statistical Institution's (TUIK) indices for measuring quality of life, in order to see national data on quality of life and compare the indices in world with Turkey.

Table 1: Qualifications of selected papers on quality of life

\begin{tabular}{l|l|l|l|l|l|l}
\hline & Micro/Macro Scale & $\begin{array}{c}\text { Empirical/ } \\
\text { Conceptual }\end{array}$ & $\begin{array}{c}\text { Objective / } \\
\text { Subjective Data }\end{array}$ & $\begin{array}{c}\text { National Database / } \\
\text { Research Based Data }\end{array}$ & Method & Study Area \\
\hline $\begin{array}{l}\text { Berkoz et al., } \\
2009 \\
\begin{array}{l}\text { Blomquist et al., } \\
1988\end{array}\end{array}$ & Macro & Empirical & Subjective & Research Based Data & Questionnaire & Istanbul/Turkey \\
& Empirical & Objective & National Database & Analytical Model & USA Counties
\end{tabular}




\begin{tabular}{|c|c|c|c|c|c|c|}
\hline $\begin{array}{l}\text { Bölen et al., } \\
2007\end{array}$ & Micro & Empirical & Objective & Research Based Data & \begin{tabular}{|l} 
Spatial \\
Calculations
\end{tabular} & | Istanbul/Turkey \\
\hline Das, D., 2008 & Macro & Empirical & Subjective & Research Based Data & Questionnaire & Guwahati//India \\
\hline $\begin{array}{l}\text { Discoli, C. et al., } \\
2014\end{array}$ & Macro & Empirical & \begin{tabular}{|l} 
Objective and \\
Subjective
\end{tabular} & Research Based Data & $\begin{array}{l}\text { Maps, } \\
\text { calculations and } \\
\text { questionnaire }\end{array}$ & La Plata/Argentina \\
\hline $\begin{array}{l}\text { Dülger Türkoğlu } \\
\text { et al., } 2009\end{array}$ & Macro and Micro & Empirical & Subjective & $\begin{array}{l}\text { Research Based Data and } \\
\text { National Database }\end{array}$ & Interviews & | Istanbul/Turkey \\
\hline $\begin{array}{l}\text { El Din et al., } \\
2013\end{array}$ & Macro & Conceptual & - & - & - & - \\
\hline $\begin{array}{l}\text { Fornara et al., } \\
2010\end{array}$ & Micro & Empirical & Subjective & Research Based Data & Questionnaire & $\begin{array}{l}\text { Agrigento, Bologna, } \\
\text { Cesena, Florence, } \\
\text { Grosseto, L'Aquila, } \\
\text { Latina, Matera, Palermo, } \\
\text { Pescara, and Salerno / } \\
\text { Italy }\end{array}$ \\
\hline $\begin{array}{l}\text { Hassine et al., } \\
2014\end{array}$ & Micro & Empirical & Subjective & Research Based Data & Questionnaire & $\begin{array}{l}\text { Tunis, Sousse, and Sfax } \\
\text { /Tunusia }\end{array}$ \\
\hline Karim, 2012 & Micro & Conceptual & - & - & - & - \\
\hline Keles, 2012 & Macro & Conceptual & - & - & - & - \\
\hline Khalil, 2012 & Macro & Conceptual & - & - & - & $\begin{array}{l}\text { AlShohada and Badr } \\
\text { /Egypt }\end{array}$ \\
\hline $\begin{array}{l}\text { Lloyd \& Auld, } \\
2003\end{array}$ & Macro & Conceptual & - & - & - & - \\
\hline Marans, 2012 & Macro and Micro & Conceptual & - & - & - & - \\
\hline $\begin{array}{l}\text { Oktay, D. et al., } \\
2009\end{array}$ & Micro & Empirical & Subjective & $\begin{array}{l}\text { Research Based Data and } \\
\text { National Database }\end{array}$ & \begin{tabular}{|l} 
Face to face \\
interviews
\end{tabular} & Famagusta/Cyprus \\
\hline Rogerson, 1999 & Macro & Conceptual & - &  & - & - \\
\hline $\begin{array}{l}\text { Sirgy, M. } \\
\text { Cornwell, } \\
2002\end{array}$ & Micro & Empirical & Subjective & Research Based Data & Questionnaire & $\begin{array}{l}12 \text { counties of western } \\
\text { Virginia }\end{array}$ \\
\hline $\begin{array}{l}\text { Soleimani et al., } \\
2014\end{array}$ & Micro & Empirical & Subjective & Research Based Data & Questionnaire & | Tehran/Iran \\
\hline $\begin{array}{l}\text { Türkoğlu et al., } \\
2011\end{array}$ & Macro and Micro & Empirical & Subjective & $\begin{array}{l}\text { Research Based Data and } \\
\text { National Database }\end{array}$ & $\begin{array}{l}\text { Face to face } \\
\text { interviews }\end{array}$ & | Istanbul/Turkey \\
\hline $\begin{array}{l}\text { Zainal et al., } \\
2012\end{array}$ & Micro & Empirical & Subjective & Research Based Data & Questionnaire & $\begin{array}{l}\text { Kuala Lumpur, Petaling } \\
\text { Jaya, Shah Alam, and } \\
\text { Klang/Malaysia }\end{array}$ \\
\hline
\end{tabular}

\section{Quality of life}

The parameters of quality of life are diverse. Regarding only the spatial data the parameters can be categorized into 8 headings; residential, transport, safety, environment, socio-cultural, recreational, educational and health (Table 2). Among these dimensions, transportation, residential and environment involved the highest number of parameters. Public transport, accessibility to educational and health facilities, aesthetics of the built environment, safety and security, clean water, air quality, educational facilities, solid waste disposal system, noise pollution, parks and green areas are the most repeated and concerned parameters in all papers. Most of the parameters are measured by subjective data which are based on questionnaires and face 
to face interviews. Only a few of these parameters were objective data; based on calculations, mathematical models and/or mapping. While collecting subjective data likert scale survey questions were asked to understand the respondents' satisfaction on various issues such as aesthetics of the built environment, public transport or solid waste disposal system (Fornara et al, 2010; Karim, 2011; Türkoğlu et al., 2011). Objective data were collected via geographic information systems to calculate parameters related to building density, average building age on the street or width of street (Berköz et al., 2009; Bölen et al., 2007)

Table 2: Indicators of quality of life

\section{RESIDENTIAL}

Size of the housing area (Berköz et al., 2009)

Closeness of buildings (Berköz et al., 2009)

Number of floors (Bölen et al., 2007)

Area of parcel (Bölen et al., 2007)

Width of parcel (Bölen et al., 2007)

Building density (Bölen et al., 2007; Fornara et al, 2010)

Number of dwelling units in the building (Bölen et al., 2007)

Population density (Bölen et al., 2007; Hassine et al., 2014; Oktay et al., 2009; Soleimani et al., 2014; Zainal et al., 2012)

Age of building (Bölen et al., 2007)

Average building age on the street (Bölen et al., 2007)

Age of the subdivision on the site (Bölen et al., 2007)

Building volume (Fornara et al, 2010)

Upkeep of homes and yards (Sirgy and Cornwell, 2002; Zainal et al., 2012)

Slope of the parcel (Bölen et al., 2007)

Orientation of the parcel (Bölen et al., 2007)

Existence of a pleasant view (Bölen et al., 2007)

Quality of the building (Bölen et al., 2007; Hassine et al., 2014; Soleimani et al., 2014; Türkoğlu et al., 2011)

Conditions of housing (Das, 2008; Dülger Türkoğlu et al. 2009; Soleimani et al., 2014; Zainal et al., 2012)

Upkeep of heritage and historical remains (El Din et al., 2013)

Aesthetics of the built environment (Berköz et al., 2009; Discoli et al., 2014; El Din et al., 2013;Fornara et al, 2010; Hassine et al., 2014; Karim, 2011; Türkoğlu et al., 2011)

Housing types (El Din et al., 2013; Zainal et al., 2012)

Public places (El Din et al., 2013; Türkoğlu et al., 2011)

Macroupkeep and microupkeep (Dülger Türkoğlu et al., 2009; Fornara et al, 2010; Türkoğlu et al., 2011)

Development process: planned/ unplanned (Bölen et al., 2007)

Neighborhood improvement (Sirgy and Cornwell, 2002)

Neighborhood attractions (Soleimani et al., 2014)

\section{TRANSPORT}

Accessibility to city centre (Berköz et al., 2009; Bölen et al., 2007; Karim, 2011; Rogerson, R. J:, 1999)

Distance to district centre (Bölen et al., 2007)

Distance to nearest main street (Bölen et al., 2007)

Distance to airport (Bölen et al., 2007)

Distance to seaside (Bölen et al., 2007)

Distance to nearest kindergarten (Bölen et al., 2007)

Quality and accessibility of public transport and public transport stops (Berköz et al., 2009; Bölen et al., 2007; Das, 2008; Discoli et al., 2014; Dülger Türkoğlu et al., 2009; El Din et al., 2013; Hassine et al., 2014; Marans, 2011; Rogerson, R. J:, 1999; Soleimani et al., 2014; Türkoğlu et al., 2011)

Traffic density (Berköz et al., 2009; Das, 2008; El Din et al., 2013; Hassine et al., 2014; Oktay et al., 2009) 
Traffic roads (Berköz et al., 2009; Discoli et al., 2014; El Din et al., 2013; Oktay et al., 2009)

Safety against traffic accidents (Berköz et al., 2009; El Din et al., 2013)

Ratio of parking area (Berköz et al., 2009; Bölen et al., 2007)

External connections ( Fornara et al, 2010)

Internal functionality (El Din et al., 2013; Fornara et al, 2010)

Length of travel in time and distance (Türkoğlu et al., 2011)

Accessibility to work (Berköz et al., 2009; Soleimani et al., 2014)

Accessibility to places of entertainment (Berköz et al., 2009)

Accessibility to shopping centre (Berköz et al., 2009; Marans, 2011; Soleimani et al., 2014)

Accessibility to the market where daily needs are obtained (Berköz et al., 2009)

Accessibility to gas station (Soleimani et al., 2014)

Accessibility to elementary schools (Berköz et al., 2009; Bölen et al., 2007; El Din et al., 2013; Karim, 2011; Sirgy and Cornwell, 2002; Soleimani et al., 2014; Türkoğlu et al., 2011)

Accessibility to high schools (Berköz et al., 2009; El Din et al., 2013; Karim, 2011; Sirgy and Cornwell, 2002; Soleimani et al., 2014; Türkoğlu et al., 2011)

Accessibility to parking areas (Berköz et al., 2009; Soleimani et al., 2014; Türkoğlu et al., 2011)

Accessibility to walking areas (Berköz et al., 2009)

Accessibility to sports centres (Berköz et al., 2009; Karim, 2011; Soleimani et al., 2014)

Accessibility to local clinics (Berköz et al., 2009; Soleimani et al., 2014)

Accessibility to hospital (Berköz et al., 2009; El Din et al., 2013; Karim, 2011; Sirgy and Cornwell, 2002; Soleimani et al., 2014)

Accessibility to housing area (Rogerson, R. J:, 1999)

Quality of pedestrian paths and walkability (Berköz et al., 2009; Discoli et al., 2014; Hassine et al., 2014; Soleimani et al., 2014; El Din et al., 2013;

Türkoğlu et al., 2011)

Status of the street (Bölen et al., 2007; El Din et al., 2013; Hassine et al., 2014; Oktay et al., 2009; Türkoğlu et al., 2011)

Type of pavement (Bölen et al., 2007)

Width of street (Bölen et al., 2007)

Width of pavement (Bölen et al., 2007)

Slope of the street (Bölen et al., 2007)

\section{SAFETY}

Street lighting in the neighborhood (Sirgy and Cornwell, 2002)

Perception of general safety in the housing area and in the neighbourhood (Berköz et al., 2009; Discoli et al., 2014; Fornara et al, 2010; Hassine et al., 2014; Marans, 2011; Oktay et al., 2009; Rogerson, R. J:, 1999; Türkoğlu et al., 2011; Zainal et al., 2012)

Actual and perceived level of crime (Karim, 2011; Rogerson, R. J:, 1999; Soleimani et al., 2014; Türkoğlu et al., 2011)

\section{ENVIRONMENT}

Level of environmental pollution in the city (Das, 2008; Rogerson, R. J:, 1999; Soleimani et al., 2014)

Sanitation (Das, 2008; Discoli et al., 2014; Karim, 2011)

Clean water (Berköz et al., 2009; Bölen et al., 2007; Das, 2008; Discoli et al., 2014; El Din et al., 2013; Karim, 2011; Marans, 2011)

Drainage system (Das, 2008; Hassine et al., 2014; Karim, 2011)

Water supply duration (Das, 2008)

Source of water (Das, 2008; Discoli et al., 2014)

Sewerage system (Bölen et al., 2007; Discoli et al., 2014; Hassine et al., 2014; Soleimani et al., 2014)

Solid waste disposal system (Das, 2008; El Din et al., 2013; Hassine et al., 2014; Karim, 2011; Soleimani et al., 2014; Türkoğlu et al., 2011)

Hazardous waste (Discoli et al., 2014; Marans, 2011; Soleimani et al., 2014; Türkoğlu et al., 2011)

Air quality (Das, 2008; Discoli et al., 2014; El Din et al., 2013; Hassine et al., 2014; Marans, 2011; Türkoğlu et al., 2011)

Noise pollution (Das, 2008; Discoli et al., 2014; Hassine et al., 2014; Karim, 2011; Marans, 2011; Oktay et al., 2009; Soleimani et al., 2014; Türkoğlu et al., 2011; Zainal et al., 2012)

Odors (Hassine et al., 2014; Karim, 2011) 
Natural gas (Berköz et al., 2009; Bölen et al., 2007; Discoli et al., 2014)

Access to telephone and cable television (Berköz et al., 2009; Discoli et al., 2014; Karim, 2011)

Access to electricity (Berköz et al., 2009; Discoli et al., 2014; Karim, 2011)

Minimization of energy demand (El Din et al., 2013)

Climate (Rogerson, R. J:, 1999)

Loss of natural spaces (Türkoğlu et al., 2011)

Safety against natural disasters (earthquake, flood, etc.) (Berköz et al., 2009)

\section{SOCIO-CULTURAL}

Presence of / satisfaction with shopping facilities (Berköz et al., 2009; Das, 2008; Hassine et al., 2014; Rogerson, R. J:, 1999; Türkoğlu et al., 2011)

Presence of / satisfaction with socio-cultural activities and resources (Berköz et al., 2009; Fornara et al, 2010; Marans, 2011; Rogerson, R. J:, 1999)

Presence of / satisfaction with leisure facilities (cafe's, restaurants, cultural places) (Hassine et al., 2014)

\section{RECREATIONAL}

Presence of / satisfaction with open space (Bölen et al., 2007; Das, 2008)

Presence of / satisfaction with liveable space (Bölen et al., 2007)

Presence of / satisfaction with landscape and scenery (Berköz et al., 2009; Karim, 2011; Sirgy and Cornwell, 2002)

Presence of / satisfaction with recreation area (Bölen et al., 2007; Das, 2008; Marans, 2011; Oktay et al., 2009; Rogerson, R. J:, 1999)

Presence of / satisfaction with parks and green areas (Berköz et al., 2009; Bölen et al., 2007; Das, 2008; Discoli et al., 2014; El Din et al., 2013; Hassine et al., 2014; Marans, 2011; Oktay et al., 2009; Soleimani et al., 2014; Türkoğlu et al., 2011)

Presence of / satisfaction with walking areas (Berköz et al., 2009; Dülger Türkoğlu et al., 2009; Marans, 2011; Oktay et al., 2009)

Presence of / satisfaction with relaxation areas (Berköz et al., 2009)

Presence of / satisfaction with sport fields and sport centres (Berköz et al., 2009; Bölen et al., 2007; Fornara et al, 2010; Hassine et al., 2014)

Presence of / satisfaction with children's playgrounds and outdoor play space (Berköz et al., 2009; Karim, 2011; Marans, 2011; Sirgy and Cornwell, 2002; Türkoğlu et al., 2011)

Presence of / satisfaction with night lighting (Berköz et al., 2009; Discoli et al., 2014)

\section{EDUCATIONAL}

Quality of educational facilities (Berköz et al., 2009; Discoli et al., 2014; Fornara et al, 2010; Marans, 2011; Rogerson, R. J:, 1999; Soleimani et al., 2014)

\section{HEALTH}

Quality of health facilities (Berköz et al., 2009; Das, 2008; Discoli et al., 2014; Türkoğlu et al., 2011)

Health care/public health and sanitation (Rogerson, R. J:, 1999; Soleimani et al., 2014; Türkoğlu et al., 2011)

Social care services (Fornara et al, 2010)

Number of visits to doctors (Marans, 2011)

OECD, argued that they have been working to identify the best way to measure the progress societies for decades, measures the quality of life among countries. There are eleven dimensions regarding to quality of life in OECD'S index:

- Housing

- Income

- Jobs

- Community

- Education

- Environment

- Civic Engagement

- Health 
- Life Satisfaction

- Safety

- Work-Life Balance

Among these dimensions, the ones deal with spatial information are housing, environment and safety. Yet when the subheadings were investigated, it seems that they are indirectly related to physical environment. For example, housing indices included data related to housing expenditure, dwellings with basic facilities and rooms per person, which are more related to economic dimensions rather than physical environmental issues. Environmental indices are only measured by water quality and air pollution (Organisation for Economic Co-operation and Development (OECD), n.d.).

WHO, which has a subgroup WHOOQOL, (World Health Organization Quality of Life), has developed a quality of life assessment to be applicable cross-culturally with fifteen international field centers. The assessment has six domains:

- Physical

- Psychological

- Level of Independence

- Social Relationships

- Environment

- Spirituality/Religion/Personal Beliefs

Among these dimensions environment focuses more on collecting spatial data with questions related to home environment, health and social care: accessibility and quality, opportunities for acquiring new information and skills, participation in and opportunities for recreation/ leisure activities, physical environment (pollution/noise/traffic/climate), transport as:

- How important to you is your home environment?

- How important to you is it being able to get adequate health care?

- How important to you is it being able to get adequate social help?

- How important to you are chances for getting new information or knowledge?

- How important to you is relaxation/leisure?

- How important to you is your environment? (e.g. pollution, climate, noise, attractiveness)?

- How important to you is adequate transport in your everyday life? (World Health Organization Quality of Life Group (WHOQOL), 2012)

TUIK, which is a governmental institution and collects statistics data in all cities of Turkey, works on measurements related to life satisfaction since 2003. According to the research, which is conducted in 2014, life satisfaction is measured in six dimensions:

- Life Standards of Household

- Individual Happiness and Self-satisfaction

- Satisfaction with Public Services

- Expectation, Personal Development and Hope

- Values

- Perspective to European Union

Among these dimensions, only satisfaction with public services seems to be related to physical environment. This dimension searches satisfaction with health facilities, satisfaction with educational facilities, safety in and around schools, accessibility to schools, safety of housing environment, satisfaction with transportation services, satisfaction with services of municipalities and special provincial administration (disposal of waste, water supply, street lighting, cleaning services, sewage system service, public transportation services, upkeep of streets, amount of green spaces, sport facilities, air pollution) (Turkish Statistical Institution, 2015).

\section{Evaluation and Conclusion}

Quality of life, which is simply defined as general well-being of individuals and societies, has been studied by various 
disciplines. Focused on the perspective of environmental studies, although there has been a voluminous literature, which covers research on different scales from diverse geographies there is still gap in identifying the specific indicators of QOL for local variations and different scales (region / state, city, neighbourhood). It is a matter of all research to define what quality of life is and how it can be measured. This study made an overview of quality of life literature, which has an approach of environmental psychology. In this study the parameters related to quality of life, which were discussed in empirical studies, conceptual studies and national and local databases were listed and categorized after eliminating the ones unrelated to local conditions in Turkey. Recall, this study examined measurement methods of OECD, WHO, and TUIK. It is seen that there are various indices to measure quality of life, and these measurements are made both by subjective data and objective data. Furthermore, OECD, WHO and TUIK have less spatial indicators compared to empirical studies.

The literature review showed that, the parameters discussed in empirical studies were parallel and mostly fall into the same categories. However, OECD, WHO and TUIK have more different parameters than empirical studies and their indices lack physical environmental content. Although, TUIK seems to have more indices related to urban data, it is limited to satisfaction with the services of municipalities.

This study highlights that, in measuring quality of life, parameters which can be adapted to all urban areas should be chosen such as population density, safety against traffic accidents, air quality, and leisure facilities. In contrast, when measuring quality of life locally parameters which are specific to that area should be well observed and taken into consideration. For instance, race relations in the community might be an important parameter for people in the United States, where race variation could be observed. However, this issue would not make any sense for people in Turkey where race variation could not be observed. Another example can be considering amount of rodents in measuring quality of life in Tunisian cities, which is not applicable in Turkish cities.

Before any general conclusion limitations of this study should be acknowledged to identify the new directions of future research. First, this study reviewed a small sample of studies and it did not select the studies in a systematical way. Future research could extend the literature using a systematical approach to select studies to be reviewed. This study aimed to stress the necessity to define uniform parameters and their measures for different scale environments in Turkey however identifying such uniform parameters are beyond the scope of this study. More research are on call to develop a uniform set of parameters and their measures in different scales in Turkey. When such scales are developed it would be possible to compare the QOL in different regions, cities and neighbourhoods. Such comparisons would lead the development of policy guidelines in national and local levels.

Finally, this study aims to pave the way to develop a model to measure quality of life in Turkish cities. In this model there are eight dimensions, which are residential, transport, safety, environment, socio-cultural, recreational, educational and health related. Residential, transport and environment dimensions have the most parameters. Public transport, accessibility to educational and health facilities, aesthetics of the built environment, safety and security, clean water, air quality, educational facilities, solid waste disposal system, noise pollution, parks and green areas are the most mentioned parameters by researchers.

In conclusion, before measuring quality of life across countries or cities, first it should be well analyzed how to measure it. Especially, global institutions should collaborate with researchers and take studies in literature into consideration to identify general parameters, and local institutions should well analyze their cities or neighborhoods via in collaboration with researchers and municipalities to find out their parameters.

\section{References}

Berkoz, L., Turk, Ş. Ş., \& Kellekci, Ö. L. (2009). Environmental quality and user satisfaction in mass housing areas: the case of Istanbul.

Blomquist, G. C., Berger, M. C., \& Hoehn, J. P. (1988). New estimates of quality of life in urban areas. The American Economic Review, 89-107.

Bolen, F., Türkoğlu, H., Ergun, N., Yirmibeşoğlu, F., Terzi, F., Kaya, S., \& Kundak, S. (2007, August). Quality of residential environment in a city facing unsustainable growth problems: Istanbul. In Joint Congress of the European Regional Science Association and the Association de Science Régionale de Langue Française, Paris, August/September.

Das, D. (2008). Urban quality of life: A case study of Guwahati. Social Indicators Research, 88(2), 297-310.

Discoli, C., Martini, I., San Juan, G., Barbero, D., Dicroce, L., Ferreyro, C., \& Esparza, J. (2014). Methodology aimed at evaluating urban life quality levels.Sustainable Cities and Society, 10, 140-148.

Dülger Türkoğlu, H., Bölen, F., Baran, P. K., \& Marans, R. W. (2009). İstanbul'da yaşam kalitesinin ölçülmesi. ITÜDERGisi/a, 7(2). 
El Din, H. S., Shalaby, A., Farouh, H. E., \& Elariane, S. A. (2013). Principles of urban quality of life for a neighborhood. HBRC Journal, 9(1), 86-92.

Fornara, F., Bonaiuto, M., \& Bonnes, M. (2010). Cross-validation of abbreviated perceived residential environment quality (PREQ) and neighborhood attachment (NA) indicators. Environment and Behavior, 42(2), 171-196.

Gregory, D., Johnston, R., Pratt, G., Watts, M., \& Whatmore, S. (Eds.). (2011). The dictionary of human geography. John Wiley \& Sons.

Hassine, K., Marcouyeux, A., Annabi-Attia, T., \& Fleury-Bahi, G. (2014). Measuring Quality of Life in the Neighborhood: The Cases of Air-Polluted Cities in Tunisia. Social Indicators Research, 119(3), 1603-1612.

Karim, H. A. (2012). Low Cost Housing Environment: Compromising Quality of Life?. Procedia-Social and Behavioral Sciences, 35, 44-53.

Keles, R. (2012). The Quality of Life and the Environment. Procedia-Social and Behavioral Sciences, 35, 23-32.

Khalil, H. A. E. E. (2012). Enhancing quality of life through strategic urban planning. Sustainable Cities and Society, 5, 77-86.

Lloyd, K., \& Auld, C. (2003). Leisure, public space and quality of life in the urban environment. Urban policy and research, 21(4), 339-356.

Marans, R. W. (2012). Quality of urban life studies: An overview and implications for environment-behaviour research. Procedia-Social and Behavioral Sciences, 35, 9-22.

Mohit, M. A. (2013a). Quality of Life in Natural and Built Environment-An Introductory Analysis. Procedia-Social and Behavioral Sciences, $101,33-43$.

Mohit, M. A. (2013b). Objective analysis of variation in the regional quality of life in Malaysia and its policy implications. Procedia-Social and Behavioral Sciences, 101, 454-464.

Oktay, D., Rüstemli, A., \& Marans, R. W. (2009). Neighborhood satisfaction, sense of community, and attachment: Initial findings from Famagusta quality of urban life study. ITU A/Z Journal, 6(1), 6-20.

Organisation for Economic Co-operation and Development (OECD). How's Life. (n.d.). Retrieved from http://www.oecdbetterlifeindex.org/

Rogerson, R. J. (1999). Quality of life and city competitiveness. Urban studies,36(5-6), 969-985.

Sirgy, M. J., \& Cornwell, T. (2002). How neighborhood features affect quality of life. Social indicators research, 59(1), 79-114.

Soleimani, M., Tavallaei, S., Mansuorian, H., \& Barati, Z. (2014). The Assessment of Quality of Life in Transitional Neighborhoods. Social Indicators Research, 119(3), 1589-1602.

Türkiye İstatistik Kurumu (TUIK). (2015). Yaşam Memnuniyeti Araştırması, 2014. Türkiye İstatistik Kurumu Matbaası, Ankara.

Türkoğlu, H., Bölen, F., Baran, P. K., \& Terzi, F. (2011). Measuring quality of urban life in Istanbul. In Investigating quality of urban life (pp. 209-231). Springer Netherlands.

World Health Organization Quality of Life Group (WHOQOL). (2012). WHOQOL-SRPB Field-Test Instrument. World Health Organization, Geneva.

Zainal, N. R., Kaur, G., Ahmad, N. A., \& Khalili, J. M. (2012). Housing conditions and quality of life of the urban poor in Malaysia. Procedia-Social and Behavioral Sciences, 50, 827-838. 